\title{
The Impact of Working Capital Management on Solvency: Empirical Study From Listed Companies in Vietnam
}

\author{
Dau Hoang Hung ${ }^{1}$, Nguyen Viet $\mathrm{Ha}^{1}$, Ha Thu Huyen ${ }^{1} \&$ Tran Thi Nga ${ }^{1}$ \\ ${ }^{1}$ Faculty of Accounting - Auditing, Hanoi University of Industry, Vietnam \\ Correspondence: Dau Hoang Hung, Faculty of Accounting - Auditing, Hanoi University of Industry, Vietnam. E-mail: \\ dauhoanghung@haui.edu.vn
}

Received: October 5, 2020

Accepted: December 9, 2020

Online Published: January 20, 2021

doi:10.5430/rwe.v12n2p178

URL: https://doi.org/10.5430/rwe.v12n2p178

\begin{abstract}
Working capital management has a great impact on the solvency of any business entity. This paper examines the impact of working capital management on the solvency of enterprises listed on the Vietnamese stock exchange. Data were collected from the financial statements of 395 enterprises listed on the Ho Chi Minh Stock Exchange and the Hanoi Vietnam Stock Exchange with a total of 1,580 observations in the period of 2015 - 2018. The study used Ordinary Least Square (OLS), Fixed Effect Model (FEM), and Random Effect Model (REM) to investigate the impact of some variables such as average collection period index, inventory conversion cycle index, and average payment period index on the solvency in both short and long terms. The empirical results showed that the average collection period and inventory cycle have a positive impact on short-term solvency and long-term solvency while the average payment period has the opposite impact.
\end{abstract}

Keywords: working capital, efficient use of working capital, measure working capital efficiency, solvency

\section{Introduction}

Effective working capital management plays a key role in a company's overall strategy to create shareholder value. Working capital management has a great impact on business performance, especially solvency, in particular: accelerating the recovery of receivable debts and inventory turnover will help businesses get an abundant amount of cash for production and business activities in the next cycle, reduce capital costs, storage costs, etc., and possibly improve the performance of the business. Effective working capital management is a real issue that attracts corporate executives' attention to fulfill their payment and profit goals. Therefore, ineffective working capital management not only reduces profits but can even lead to insolvency and financial crisis of the business. Besides, for any business organization, regardless of the profit orientation, size, and business nature, it is necessary to have a certain amount of working capital. The correct estimation of working capital is essential and is a difficult task for managers because different companies have different working capitals, depending on the business nature, sector, scale of operation, production cycle, credit policy, availability of raw materials, etc. So, good working capital management is also an important indicator of the fair health of a business, which requires an accurate assessment and prevention of unnecessary use of loan capital to reduce financial costs. From there, it can be seen that effective management of working capital is an important factor in maintaining the existence, solvency, and profitability of any business organization.

Considering the indisputable importance of effective working capital management, many managers have attempted to study the relevance of short-term assets and short-term liabilities to strike a balance between business risk and efficiency. In the current context in Vietnam, the reality of working capital management of listed companies on the Vietnamese stock exchange is an emerging issue, requiring empirical studies that provide scientific evidence to ensure high accuracy and help information users to have a reliable basis to make appropriate decisions.

\section{Literature Review}

To examine the impact of working capital management on the liquidity and solvency of small and medium enterprises, Sunday (2011) used data of Nigerian companies. According to research results, small companies have weak financial status because they rely tooheavily on commercial credit for daily operations.

Eljelly (2004) examined the relationship between solvency and profitability where solvency is measured by 
short-term solvency and cash flow timing on a sample that includes Saudi Arabia's listed companies. Using correlation regression analysis, this study indicated that there was an inverse correlation between profitability and solvency. This correlation was more evident in firms with high solvency ratio and long turnaround times. However, in these firms, there was also evidence that the cash flow timing had a bigger impact than short-term solvency.

Shin \& Soenen (1998) used correlation and regression analysis for a large sample of 58,895 US firms in the period of 1975-1994 to demonstrate the relationship between circulating capital management and the ability to create value for shareholders. The results indicated a strong inverse relationship. It implied that managers can increase corporate performance and create value for shareholders by reducing the net trading cycle to the minimum fair value.

Dong \& Su (2010) studied secondary data collected from listed firms in the Vietnamese stock exchange from 2006 to 2008 to investigate the relationship existing between profitability, the cash conversion cycle, and its components for listed firms on the Vietnamese stock exchange. Their finding showed that there was a strong negative relationship between profitability, measured through gross operating profit, and the cash conversion cycle. This means that as the cash conversion cycle increases, it will lead to the decline of a firm. Therefore, the managers can create positive shareholders' value by identifying the appropriate cash conversion cycle and maintaining each different component at optimal levels.

Lyroudi \& McCarty (1993) indicated that the cash conversion cycle was negatively related to the current ratio, the inventory conversion period, and the payables deferral period, but positively related to the quick ratio and the receivables conversion period.

Moss \& Stine (1993) indicated that larger retail firms had shorter CCCs, which implies that smaller companies should try to better manage their cash conversion cycle. The relationship between the cash conversion cycle and the current and quick ratios was found positive and significant, indicating that although strong current and quick ratios are generally desirable, they could imply a large investment in working capital which could lead to problems if not taken into consideration.

Appuhami (2008) investigated the impact of firms' capital expenditure on their working capital management. The author used the data collected from listed companies on the Thailand Stock Exchange. This empirical research found that firms' capital expenditure had a significant impact on working capital management. The study also found that the firms' operating cash flow, which was recognized as a control variable, had a significant relationship with working capital management.

Braun \& Larrain (2005) found that high working capital requirements were a key determinant of a business' dependence on external financing. They showed that firms that were highly dependent on external financing were more affected by recessions and should take more precautions in preparing for declines in the economic environment, including ensuring a secure level of working capital reserves during times of crisis.

ALShubiri (2011) studied the relationship between aggressive and conservative working capital practices and profitability as well as risk. The sample included 59 industrial firms and 14 banks listed on the Amman Stock Exchange from 2004 to 2008. The results indicated a negative relationship between profitability measures and working capital aggressiveness, investment, and financing policy. Firms yield negative returns if they follow an aggressive working capital policy. In general, there was no statistically significant relationship between the level of current assets and current liabilities on operating and financial risk in industrial firms.

Ouma (2001) studied cash management approaches employed by companies listed on the Nairobi Securities Exchange, Kenya. From a sample of 27 companies, the findings of this study indicated that listed companies apply specific policies in the management of their cash balances and plan for their cash balances. They have more than one planning period and the weekly planning period is the most popular.

Richards and Laughlin (1980) argued that traditional ratios such as current ratio, Quick/Acid Test Ratio, and cash ratios have not been able to provide accurate information about working capital and insisted on using ongoing liquidity measures in working capital management, where ongoing liquidity refers to the inflows and outflows of cash as a product of acquisition, production, sales, payment and collection process done over time. The firm's ongoing liquidity is a function of its cash conversion cycle, hence the appropriateness of evaluation by cash conversion cycle, rather than liquidity measures.

Thao (2015), N. H. Dang, Hoang, \& Tran (2017), Hung, Van, \& Hung(2020), Van Linh, Hung, Dang, Van, \& Anh (2019), Phuong \& Hung (2020), H. N. Dang, Pham, Nguyen, \& Nguyen (2020), Van, Hung, Van, \& Xuan (2019) researched factors that affect the working capital needs of enterprises listed on the Vietnamese stock market. Through the estimation results, the authors show that the net working capital needs of the enterprises in the market are 
influenced by the fluctuation of revenue, profitability, and cash conversion cycle. Also, the net working capital needs of each industry are different due to the specific characteristics, so it is recommended that investors should carefully analyze before making any investment decisions.

\section{The Relationship Between Working Capital Management and Solvency Through the Studies}

Sunday (2011) argued that the need to manage working capital effectively in small and medium enterprises (SMES) is still the key to the solvency and liquidity of SMES. Most SMES have little or no interest in the role of working capital, and most do not even have a standard credit policy. Many people just run their business in a way that mainly focuses on receiving cash and how their bank account situation sis. To examine the impact of working capital management on the liquidity and solvency of SMEs, James Sunday used data from Nigerian companies. The research results indicated the relationship between working capital management and solvency in small firms with weak financial status because they rely too heavily on commercial credit for daily operations. The research also showed the need to design a standard credit policy and ensure good control of the financial reporting system for SMEs. Besides, it is necessary to raise full awareness for working capital management for managers to ensure continuity, growth, and solvency.

According to Panigrahi (2014), the goal of working capital management is to allow a company to maximize operating profitability while meeting both short-term debt and operating costs, which means maintaining solvency. But the increase in profits often tends to reduce the solvency of the companies; conversely, if too much attention is paid to solvency, it tends to affect the profit. Therefore, every firm strives to maximize profits under the condition of maintaining its solvency. However, increasing profits under that condition can cause serious problems for the company such as insolvency. Therefore, effective working capital management is essential to strike a balance between the two core corporate goals, ensure profitability, and maintain a reasonably balanced, solvency. On one hand, excessive liquidity indicates the accumulation of idle funds that don't bring about any profits for the firm and on the other hand, insufficient liquidity might damage the firm's position, deteriorate the firm's credit standings and that might lead to forced liquidation of firm's assets. Afterward problems like bankruptcy and insolvency might happen. To sum up, a company unable to make profits might be termed as a sick company but, a company having no liquidity might cease to exist. However, when a company like Wal-Mart can generate profit and maximize shareholder's wealth with negative working capital, can we say that the company is on the verge of bankruptcy or is it a sign of managerial efficiency? Same is the case with ACC Limited, which Panigrahi A.K chose to study the association of its working capital with liquidity, profitability, and risk of bankruptcy for the period of 2000-2020. The study found that even with having negative working capital most of the time, the company was able to earn a good rate of return because of its aggressive working capital policy but its solvency was ultimately at a stake.

Consequently, it can be seen that there exists a relationship between working capital management and the solvency of enterprises. However, with different conditions (firm size, legal policy, field of activity ...) this relationship may differ, but in the fundamentals, if the business wants to maximize profits, the balance of solvency is a very important issue that managers need to care about, carefully consider, ensuring the harmony between the interests of shareholders and development. sustainable development of the business.

\subsection{Working Capital Management Measurement}

Inventory management: Most businesses have inventory because all buying, manufacturing, and selling processes do not happen at the same time. On the other hand, inventory is required to maintain the smooth operation of production lines and distribution operations as well as to prevent production uncertainties, so inventory management in production is very important. The impact of working capital management on solvency is measured through the inventory conversion cycle.

$$
\text { IP }=\frac{\text { Number of days in the period } * \text { Inventory value }}{\text { Cost of goods sold }}
$$

In which, the number of days in the period is calculated as 360 days.

Receivables management: Receivables management relates to decisions about whether to give credit to certain customers or not, how the process of developing a credit policy will be done, and the modes of handling accounts receivable. The establishment of a control system is necessary because, without it, accounts receivable will exceed the level that causes budget flows to decrease and the risk of loss increases. An optimal credit policy will determine the fair amount of receivables depending on the operating conditions of the company. The impact of receivable management on the solvency is measured through the average collection period (ARP) target: 


$$
\begin{aligned}
\text { Average number of days receivable } & =\frac{360}{\text { Accounts receivable turnover ratio }} \\
& =\frac{\text { Average balance of receivables }}{\text { Revenue for the period }} * 360
\end{aligned}
$$

Management of accounts payable: The specific contents of payables include: payables to sellers, suppliers of goods, services, supplies, contractors of capital construction and substantial repair; loans, interest on payable debts; unidentified asset value awaiting solution; other payables such as material compensation penalty, debt to employees, taxes and other payables to the state. To manage accounts payable, managers must know how to track accounts payable, based on which they can change their commercial credit policy on time. The impact of accounts payable management on solvency is measured through the average payment period (APP) target:

$$
\begin{aligned}
\text { Average number of settlement days } & =\frac{360}{\text { Number of cycles payable }} \\
& =\frac{\text { Average balance payable }}{\text { Cost of goods sold }} * 360
\end{aligned}
$$

\subsection{Solvency Measurement}

Solvency Measurement: The study uses 2 criteria to measure the solvency of the enterprises in the research scope: (i) Short-term solvency; (ii) Long-term solvency. In which, short-term solvency is the indicator showing how each monetary unit of short-term debt will be offset by how many monetary units of short-term assets. Therefore, the ratio of short-term debt payment is the most general indicator reflecting the ability to convert assets into money to pay short-term debts for businesses.

$$
\text { Short }- \text { term solvency ratio }=\frac{\text { Total short }- \text { term assets }}{\text { Total current liabilities }}
$$

Long-term solvency is the indicator of how much long-term debt $(\mathrm{NDH})$ is being offset by each monetary unit of long-term assets (TSDH) in which, NDH is debt with the maturity of more than 1 year and enterprises borrow long-term loans to invest in assets.

\subsection{Research Models}

$$
\text { Long }- \text { term solvency ratio }=\frac{\text { Total long }- \text { term assets }}{\text { total long }- \text { term debt }}
$$

To examine the impact of working capital management on the solvency of enterprises listed on the Vietnamese stock exchange, the paper uses a general regression model as follows:

In which,

$$
\begin{aligned}
& C R_{i t}=\alpha+\beta_{1} A R P_{i t}+\beta_{2} I P_{i t}+\beta_{3} A P P_{i t}+\varepsilon_{i t} \\
& N C R_{i t}=\alpha+\beta_{1} A R P_{i t}+\beta_{2} I P_{i t}+\beta_{3} A P P_{i t}+\varepsilon_{i t}
\end{aligned}
$$

$\alpha$ : intercept factor;

i: researched company;

t: year of research;

CR (Current Ratio);

NCR (Non Current Ratio);

ARP (Average Receivables Period);

APP (Average Payable Period);

IP (Inventory Period);

$\beta_{1}, \beta_{2}, \beta_{3}, \beta_{4}$ : regression coefficients; $\varepsilon$ : the remainder of the regression model.

\subsection{Data and Research Methods}

\subsubsection{Research Data}

Data for the study were collected from the financial statements of a total of 437 enterprises listed on the Ho Chi 
Minh Stock Exchange and the Hanoi Stock Exchange from 2015 to 2018. 395 enterprises provided full information during 2015-2018 with a total number of observations of 1,580 (395 enterprises * 4 years). Based on the theory and the measurement method of the efficiency of working capital usage, independent variables were set up and calculated from the following criteria: revenue, inventory, short-term receivables, long-term receivables, cost of goods sold. Dependent variables included: CR and NCR.

\subsubsection{Research Methods}

The study uses tabular data for the established econometric model to examine the impact of the efficiency of working capital usage on the solvency of enterprises listed on the Vietnamese stock exchange, including the HOSE and the HNX. The paper uses Stata version 13 to run regression models. The applied regression methods include the least squares regression method (OLS), the fixed effects model (FEM), and Random Effects Method (REM). Hausman test was also performed to choose the appropriate regression method for the model.

\section{Results}

Table 1. Descriptive statistics

\begin{tabular}{lccccc}
\hline Variable & Observation & Mean value & Standard deviation & Smallest value & Largest value \\
\hline ARP & 1580 & 1.198216 & 1.75856 & -0.798831 & 5.181462 \\
IP & 1580 & 1.176269 & 1.796493 & 0.598863 & 5.899426 \\
APP & 1580 & 1.779248 & 0.727683 & 0.463565 & 1.962983 \\
CR & 1580 & 1.379169 & 1.0896835 & 0.126785 & 4.208658 \\
NCR & 1580 & 1.019674 & 1.1702543 & 0.236559 & 3.161078 \\
\hline
\end{tabular}

Table 1 shows the total number of observations is 1580. After giving logarithmic values, the mean values (mean), standard deviation (Std.Dev.), smallest value (Min), and maximum value (Max) of each variable are as follows: the average collection period target (ARP) has the mean value, maximum value and smallest value of 1.198216, 5.181462 , and -0.79881 , respectively. The IP (inventory conversion cycle) has the mean value, maximum value, and smallest value of $1,176269,5.899426$, and 0.598863 , respectively. The average payment period indicator (APP) has the mean value, maximum value, and smallest value of $1,779248,1.962983$, and 0.463565 , respectively. The short-term KNT indicator (CR) has the mean value, maximum value, and smallest value of 1,379169, 4,208658, and 0.126785 , respectively. The long-term KNTTT indicator (NCR) has the mean value, maximum value, and smallest value of $1,019674,3.161078$, and 0.236559 , respectively.

The study examines the relationship between the independent variables and whether there exists a strong correlation that can lead to the multicollinearity phenomenon.

Table 2. Correlation experimental results

\begin{tabular}{llll}
\hline & ARP & IP & APP \\
\hline ARP & 1 & & \\
IP & 0.6813 & 1 & \\
APP & 0.7258 & 0.6758 & 1 \\
\hline
\end{tabular}

The results of testing the correlation of the independent variables in Table 2 show that the result of the correlation coefficient of the independent variables in the model is less than 0.8. Hence, it is not possible that there is no multicollinearity phenomenon among the independent variables. To be sure of this, the study continues to use the VIF test. 
Table 3. Results of the multi-collinearity test

\begin{tabular}{lll}
\hline Variable & VIF & 1/VIF \\
\hline APP & 2.09 & 0.466503 \\
\hline ARP & 2.03 & 0.564815 \\
\hline IP & 1.31 & 0.790162 \\
\hline Mean VIF & 1.81 & \\
\hline
\end{tabular}

The multi-collinearity phenomenon is tested with VIF value of APP 2.09, ARP 2.03, IP of 1.31, both less than 10. According to Baltagi (2008), if VIF value of independent variables in the model is not greater than 10, there is no multicollinearity phenomenon.

The study performs regression analysis of OLS, FEM, REM between the independent variables ARP, IP, APP and the dependent variables CR and NCR, and then uses the Hausman test to choose a suitable regression model.

Table 4. Regression results of the statistical analysis between independent variables and the CR

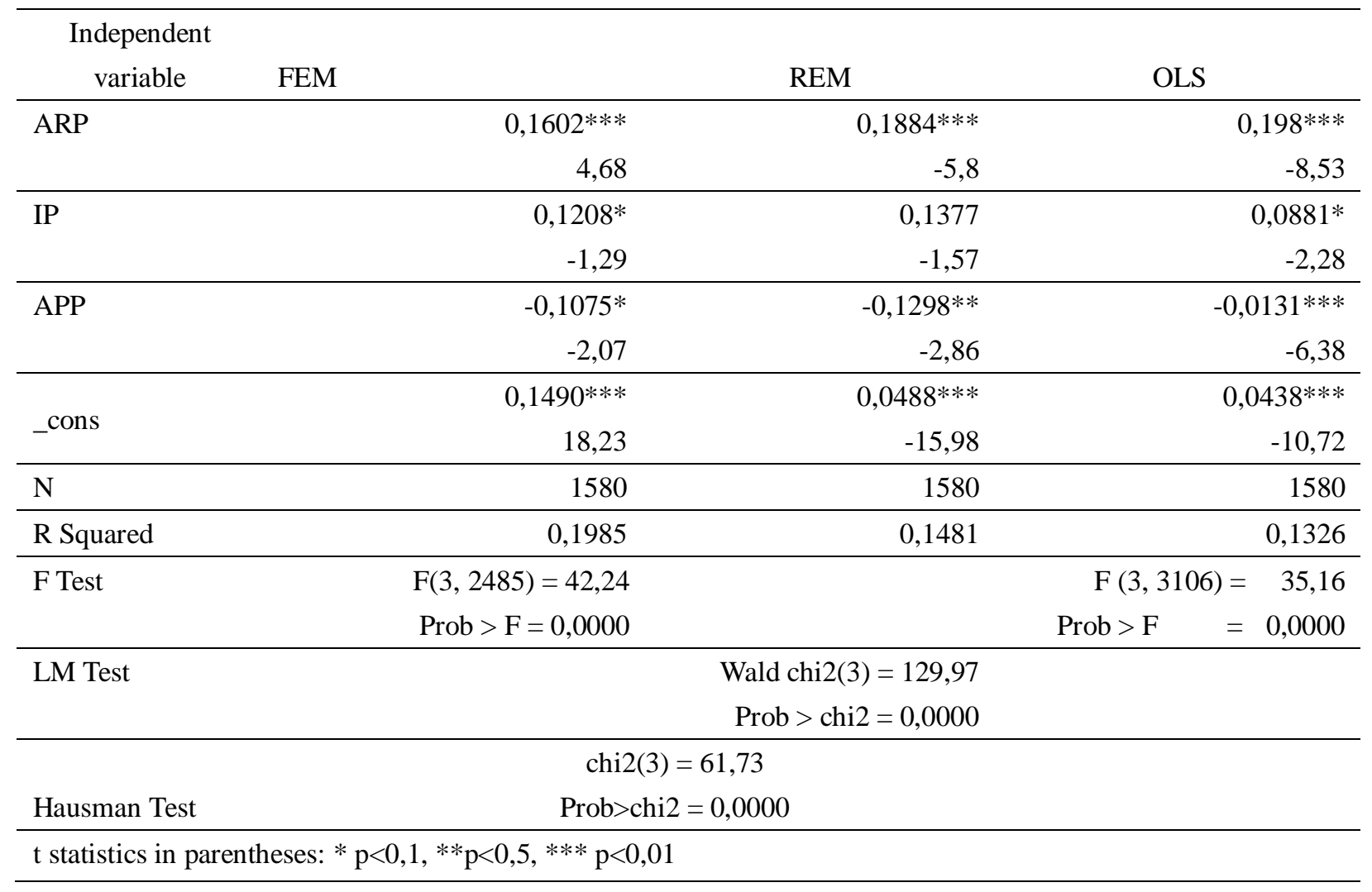

In Table 4 and Table 5, the F-test coefficients all give Prob $>\mathrm{F}=0.0000<\alpha=5 \%$, so with the significance of 5\%, the OLS regression model is not suitable for both 2 sub-variables. Belongs are CR and NCR. Besides, the results of the Hausman test for the CR regression model give Prob $>$ chi $2=0.0000<5 \%$. Therefore, the FEM model will be used. As for NCR, the Hausman test gives Prob> chi $2=0.2148>5 \%$, so the study will use REM model. 
Table 5. Statistical analysis results of regression analysis between the variables independent and the NCR

\begin{tabular}{|c|c|c|c|}
\hline $\begin{array}{c}\text { Independent } \\
\text { variable }\end{array}$ & FEM & REM & OLS \\
\hline \multirow[t]{2}{*}{$\mathrm{ARP}$} & $0,1138 * * *$ & $0,1195 * * *$ & $0,1327 * * *$ \\
\hline & $-3,87$ & $-5,48$ & $-7,94$ \\
\hline \multirow[t]{2}{*}{ IP } & 0,13869 & $0,1302 *$ & $0,1072 *$ \\
\hline & $-1,97$ & $-2,18$ & $-2,73$ \\
\hline \multirow[t]{2}{*}{ APP } & $-0,1097$ & $-0,1381^{*}$ & $-0,1192 * * *$ \\
\hline & $-1,18$ & $-2,38$ & $-5,87$ \\
\hline \multirow{2}{*}{ _cons } & $0,1479 * * *$ & $0,1552 * * *$ & $0,1568 * * *$ \\
\hline & $-18,97$ & $-17,76$ & $-15,81$ \\
\hline $\mathrm{N}$ & 1580 & 1580 & 1580 \\
\hline R Squared & 0,1675 & 0,18462 & 0,1559 \\
\hline \multirow[t]{2}{*}{ F Test } & $\mathrm{F}(3,2485)=40,32$ & & $\mathrm{~F}(3, \quad 3106)=38,23$ \\
\hline & Prob $>F=0,0000$ & & Prob $>F=0,0000$ \\
\hline \multirow[t]{2}{*}{ LM Test } & \multirow{2}{*}{\multicolumn{3}{|c|}{$\begin{aligned} \text { Wald chi2 } 2(3) & =135,61 \\
\text { Prob }>\text { chi } 2 & =0,0000\end{aligned}$}} \\
\hline & & & \\
\hline \multicolumn{4}{|c|}{$\operatorname{chi} 2(3)=0,073$} \\
\hline Hausman Test & \multicolumn{2}{|c|}{ Prob $>$ chi $2=0,2148$} & \\
\hline \multicolumn{4}{|c|}{$\mathrm{t}$ statistics in parentheses $* \mathrm{p}<0,1 ; * * \mathrm{p}<0,5 ; * * * \mathrm{p}<0,01$} \\
\hline
\end{tabular}

To sum up, the regression model includes the following:

$$
\begin{aligned}
C R_{i t} & =0,1490+0,1602 A R P_{i t}+0,1208 \mathrm{IP}-0,1075 A P P_{i t} \\
N C R_{i t} & =0,1552+0,1195 A R P_{i t}+0,1302 \mathrm{IP}_{i t}-0,1381 A P P_{i t}
\end{aligned}
$$

\section{Conclusion and Recommendation}

\subsection{Conclusion}

Experimental study using a sample of 1,580 observations, collected from 395 listed companies on the Vietnamese stock exchange from 2015 to 2018. Various regression methods are applied, including OLS, FEM, REM with independent variables of average collection period (ARP), inventory conversion cycle (IP), cash conversion cycle (APP) and dependent variables of short-term solvency (CR), and long-term solvency (NCR). The results of the study have provided useful information about the impact of components to measure the efficiency of using working capital on solvency, specifically: average collection period (ARP) and inventory conversion cycle (IP) both have positive impacts on the short-term and long-term solvency while the average payment period has a negative impact on the short-term and long-term solvency.

\subsection{Recommendation}

For managers, it is important to consider and accurately analyze the structure of short-term assets, major fluctuations in the size of working capital, and the difference among operational cycles of the demand for working capital. They must determine the need for working capital to plan capital mobilization and compare costs of capital mobilization activities from funding sources to timely choose the right capital mobilization channel for capital needs without having excess capital, capital waste, or shortage that disrupt business activities while minimizing potential risks. Besides, firms need to develop strategies on inventory and sales to effectively manage inventory, reduce costs as well as appropriate cash flow policies. It is also necessary for firms to analyze and evaluate the situation of using working capital, thereby providing timely information for the process of evaluating the effectiveness of using working capital regularly. Reasonable methods of collecting sales on credit are required so that there are specific and timely adjustments to the use of working materials. 


\section{References}

ALShubiri, F. N. (2011). The effect of working capital practices on risk management: Evidence from Jordan. Global Journal of Business Research, 5(1), 39-54.

Appuhami, B. (2008). The Impact of Firms' Capital Expenditure on Working Capital Management: An Empirical Study across Industries in Thailand. International Management Review, 4(1), 11-24.

Braun, M., \& Larrain, B. (2005). Finance and the business cycle: international, inter-industry evidence. The Journal of Finance, 60(3), 1097-1128. https://doi.org/10.1111/j.1540-6261.2005.00757.x

Dang, H. N., Pham, C. D., Nguyen, T. X., \& Nguyen, H. T. T. (2020). Effects of Corporate Governance and Earning Quality on Listed Vietnamese Firm Value. The Journal of Asian Finance, Economics and Business (JAFEB), 7(4), 71-80. https://doi.org/10.13106/jafeb.2020.vol7.no4.71

Dang, N. H., Hoang, T. V. H., \& Tran, M. D. (2017). Impact of Cost Control on Business Efficiency of Small and Medium Sized Enterprises in Thai Binh, Vietnam. International Finance and Banking, 4(2), 112.

Dong, H. P., \& Su, J.-t. (2010). The Relationship between Working Capital Management and Profitability: A Vietnam Case. International Research Journal of Finance and Economics, (49), 59-67.

Eljelly, A. M. A. (2004). Liquidity-profitability tradeoff: An empirical investigation in an emerging market. International Journal of Commerce and Management, 14(2), 48-61.

Hung, D. N., Van, V. T. T., \& Hung, N. D. (2020). The sensitivity of cash flows to cash holdings: case studies at Vietnamese enterprises. Investment Management \& Financial Innovations, 17(1), 266-276.

Lyroudi, K., \& McCarty, D. (1993). An empirical investigation of the cash conversion cycle of small business firms. Journal of Small Business Finance, 2(2), 139-161.

Moss, J. D., \& Stine, B. (1993). Cash conversion cycle and firm size: a study of retail firms. Managerial Finance, 19(8), 25-34. https://doi.org/10.1108/eb013739

Ouma, S. O. (2001). A survey of the cash management approaches employed by companies quoted at the Nairobi stock exchange. (Unpublished MBA Research project), University of Nairobi.

Panigrahi, A. K. (2014). Relationship of working capital with liquidity, Profitability and solvency: A case study of ACC limited. Asian Journal of Management Research, 4(2), 308-322. https://doi.org/10.2139/ssrn.2398413

Phuong, N., \& Hung, D. (2020). Impact of working capital management on firm profitability: Empirical study in Vietnam. Accounting, 6(3), 259-266. https://doi.org/10.5267/j.ac.2020.3.001

Richards, V. D., \& Laughlin, E. J. (1980). A cash conversion cycle approach to liquidity analysis. Financial Management, 9(1), 32-38. https://doi.org/10.2307/3665310

Shin, H. H., \& Soenen, L. (1998). Efficiency of working capital management and corporate profitability. Financial Practice and Education, 8(2), 37-45.

Sunday, K. J. (2011). Effective Working Capital Management in Small and Medium Scale Enterprises (SMEs). International Journal of Business and Management, 6(9), 271-279. https://doi.org/10.5539/ijbm.v6n9p271

Thao, L. N. P. (2015). Study factors affecting the working capital requirements of the enterprises listed on the Vietnamese stock exchange. (Unpublished MBA Research project), Da Nang University.

Van, H. T. T., Hung, D. N., Van, V. T. T., \& Xuan, N. T. (2019). Managing Optimal Working Capital and Corporate Performance: Evidence from Vietnam. Asian Economic and Financial Review, 9(9), 977-993.

Van Linh, N., Hung, D. N., Dang, T. B., Van, V. T. T., \& Anh, N. T. M. (2019). The Effects of Business Efficiency to Disclose Information of Sustainable Development: The Case of Vietnam. Asian Economic and Financial Review, 9(4), 547-558. https://doi.org/10.18488/journal.aefr.2019.94.547.558

\section{Copyrights}

Copyright for this article is retained by the author(s), with first publication rights granted to the journal.

This is an open-access article distributed under the terms and conditions of the Creative Commons Attribution license (http://creativecommons.org/licenses/by/4.0/). 